\title{
DEVELOPING INNOVATIVE FOOTWEAR DESIGNS: EMPIRICAL EVIDENCE FROM INDONESIA
}

\author{
David Sukardi KODRAT, Tina MELINDA*, Denpharanto A. KRISPRIMANDOYO \\ Universitas Ciputra, Citraland - Surabaya, Indonesia, david.kodrat@ciputra.ac.id, tina.melinda@ciputra.ac.id, \\ agungkris@ciputra.com
}

Received: 22.08 .2020

Accepted: 19.11 .2020

https://doi.org/10.24264/Ifj.20.4.7

DEVELOPING INNOVATIVE FOOTWEAR DESIGNS: EMPIRICAL EVIDENCE FROM INDONESIA

ABSTRACT. This research aims to develop innovative footwear designs using Modified Design Thinking. This research is a qualitative research with Focus Group Discussion (FGD) as data source. Additionally, Modified Design Thinking was used to analyse the research data. The research findings reinforce the use of Modified Design Thinking in developing innovative footwear designs by identifying the needs of potential customers. Furthermore, local culture is believed to be the most influential factor in footwear design. As such, the innovation process in Indonesia is unique as it incorporates local culture into the creation of footwear design. This research enriches the existing footwear design innovation from the customers' perspective by using local culture as the main innovation element.

KEY WORDS: innovation, footwear design, Modified Design Thinking, local culture

\section{DEZVOLTAREA UNOR MODELE DE ÎNCĂLȚĂMINTE INOVATOARE: DOVEZI EMPIRICE DIN INDONEZIA}

REZUMAT. Această cercetare își propune să dezvolte modele de încăltăminte inovatoare folosind metoda Modified Design Thinking. Această cercetare este una calitativă, având ca sursă de date Focus Group Discussion (FGD). În plus, metoda Modified Design Thinking a fost utilizată pentru a analiza datele cercetării. Rezultatele cercetării consolidează utilizarea metodei Modified Design Thinking în dezvoltarea de modele de încălțăminte inovatoare prin identificarea nevoilor potențialilor clienți. În plus, cultura locală pare să fie cel mai influent factor în designul încălțămintei. Ca atare, procesul de inovare din Indonezia este unic deoarece încorporează elemente din cultura locală în crearea designului încălțămintei. Această cercetare îmbogățește inovația existentă în designul încălțămintei din perspectiva clienților, utilizând cultura locală ca principal element de inovare.

CUVINTE CHEIE: inovație, design de încălțăminte, metoda Modified Design Thinking, cultură locală

\section{DÉVELOPPER DES CONCEPTIONS DE CHAUSSURES INNOVANTES : PREUVE EMPIRIQUE DE L'INDONÉSIE}

RÉSUMÉ. Cette recherche vise à développer des conceptions de chaussures innovantes en utilisant le Design Thinking modifié. Cette recherche est une recherche qualitative avec Focus Group Discussion (FGD) comme source de données. De plus, le Design Thinking modifié a été utilisé pour analyser les données de recherche. Les résultats de la recherche renforcent l'utilisation de la pensée de conception modifiée dans le développement de modèles de chaussures innovants en identifiant les besoins des clients potentiels. En outre, la culture locale est considérée comme le facteur le plus influent dans la conception des chaussures. En tant que tel, le processus d'innovation en Indonésie est unique car il intègre la culture locale dans la création de la conception de chaussures. Cette recherche enrichit l'innovation de conception de chaussures existante du point de vue des clients en utilisant la culture locale comme principal élément d'innovation.

MOTS CLÉS : innovation, conception de chaussures, Design Thinking modifié, culture locale

\footnotetext{
* Correspondence to: Tina MELINDA, Universitas Ciputra, Citraland-Surabaya, Indonesia, tina.melinda@ciputra.ac.id
} 


\section{INTRODUCTION}

The national industrial development policy has set "manufacturing industry base" as a priority industry in the formation of linkages in footwear industries [1]. The purpose of this policy is to strengthen the structure of the footwear industry by expanding the raw material supply industry, as well as other relevant supporting industries. The rapid changes in the footwear industry, paired with the globalization effects from the ASEAN Economic Community and Asian Free Trade Agreement, have significantly influenced the level of competitiveness. As a result, industries need to increase the competency of their labour force in order to compete in the global market.

Based on the data from the Department of Industry, there were as many as 398 SMEs in Mojokerto in 2015. These enterprises were located in three villages, namely Miji, Surodinawan, and Prajurit Kulon. Among the footwear manufacturers across the three villages, $19 \%$ were shoes manufacturers; $49 \%$ were slippers manufacturers; $29 \%$ were shoes and sandals manufacturers; and 3\% were shoe last makers. Overall, four major problems were encountered by the majority of these SMEs [2].

First, footwear SMEs had difficulty obtaining quality raw materials. Most enterprises were highly dependent on imported raw materials. In addition, they were occasionally forced to accept lower-quality raw materials due to the unavailability of imported materials that matched the desired specifications. They purchased raw materials directly from the stores, sales agents, distributors, or other sources such as factories, grocery stores, or malls.

Second, the business management and production system were still traditional. The business owners handled all issues personally. Furthermore, documentation system and technology utilization in the production process were very limited. Equally limited was the number of experts in the field of footwear industry.

Third, the footwear sales were based on B2B demands from other factories or wholesalers, or $\mathrm{B} 2 \mathrm{C}$ demands from individual retailers. And fourth, the coordination and synergy among stakeholders to plan and implement activities for the development of the SMEs needed improvement. Nonetheless, the footwear makers only produced by order. They were not confident enough to create their own design in fear of rejection. Hence, the purpose of this research is to develop innovative fashion footwear designs that would cater to the customers' needs.

\section{LITERATURE REVIEW}

\section{Innovation Product Development}

Innovation is considered as the success factor in a business, because the aspect allows business owners to understand customer needs and generate customer satisfaction [3]. It is also believed to be the driving force behind many contemporary successful companies [4]. Angelmar [5] defined innovative product as a new or improved product, while Reguia added that innovation process involved new techniques and means in production methods. Additionally, product innovation reflects the firm's image. In fact, the firm's success depends on the product's ability to fulfil consumers' needs and desires, from which the information will be used to develop new products [3].

Most theories distinguish innovation, innovation product, and product development as separate theories. Unfortunately, there were very few definitions on innovation product development in the scientific articles reviewed. Product development is defined as "the set of activities beginning with the perception of a market opportunity and ending with the production, sale and delivery of a product" [6]. In brief, product development could be defined as the "process of eliminating the uncertainty about the product".

Bilgili, Erciş, \& Ünal [7] argued that the need to develop new products was precipitated by the rapid growth and development of technology, expansion of marketing environment and competition, and the limited life-span of products in the market. Balachandra \& Friar [8] added that the New Product Development (NPD) and Research and Development (R\&D) projects have three dimensions: innovation (incrementalradical), technology (low-high), and market (newexisting). A fourth dimension, the nature of the 
industry, was also mentioned [8]. Several other studies suggested a different kind of conceptual model for the new product development process, which includes idea screening, commercial launching for preliminary market, and business or technical assessments [9].

The focus of the next stage of new product development is to design and develop the product. To do this, a large amount of information and knowledge is needed [9]. Su, Chen, \& Sha [10] insisted that knowledge is an asset in today's digital economy, and that managerial knowledge helps organizations develop innovative products and make strategic decisions. Additionally, technological competence and customer needs are closely related in relation to product innovation, because they provide the 'know-how' in the process of securing market acceptance [10]. Moreover, Danneels [11] proposed that knowledge management is crucial in the development of innovative products. Product and service innovation require managerial knowledge as a means to create competitive advantages for the company.

The market competition has grown rapidly in recent years. Consequently, small and medium-sized enterprises (SMEs) must survive and defend their positions through new product developments (NPDs) [12]. NPD is the strongest weapon against the growing competition [7]. As a matter of fact, many experts believed that innovative products should not be taken for granted, because the organization and its members must also be fully committed to the purpose. Therefore, SMEs employees must be equipped with the necessary skills to improve the company's product development capability as a whole.

Most of the articles reviewed in this paper discussed innovation product development (IPD) in the context of advance technology. Additionally, no universal definition could be found regarding IPD. The majority of the literature discussed innovation and product development separately, as opposed to innovation product development as a singular concept. It appears that the term 'IPD' was more frequently used in newer studies such as the ones conducted by [7] and [12].

The term New Product Development (NPD) was also used in newer articles, such as the study of [12]. However, NPD is not the same as
IPD, as new products are not always innovation products. Hence, researchers must not confuse the two terms. Based on the theory reviewed in this paper, IPD is the creation of new or improved product which may include new production techniques, as well as uncertainty in the decisionmaking process due to the lack of information concerning the product's development $[3,5,6]$. The next section will discuss about the use of Modified Design Thinking to identify the needs of potential customers in the fashion footwear industry.

\section{Modified Design Thinking}

Pink [13] argued that the current era of creativity demanded a different set of abilities from its players. As a result, there is a tendency to incorporate multiple disciplines to form a scientific viewpoint, particularly in the last two decades. In design perspective, conceptions of design thinking were introduced. The approach used by the new conceptions is quite the opposite of the traditional approach, which was problem solving.

One of the most important abilities in the creativity era is design ability. Several interpretations were made on design ability. For instance, [14] considered it as design attitude. Meanwhile, Brown [15] perceived it as design thinking. Design thinking is a series of divergent and convergent thinking processes. The essence of the divergent process is to create choices, while the essence of the convergent process is to make choices [15]. This suggestion is in line with the opinion of [13] who believed that design is a unique ability of whole thought - a combination of usefulness and meaning. In other words, design thinking optimizes the combined capacities of the left and right brains.

Design thinking is an approach that revolutionizes our thinking patterns in various areas of life and problem-solving perspectives. Therefore, design thinking often starts with the question 'What problem is being encountered?' followed by 'What is the cause of the problem?' Design thinking uses the designer's sensibility and methods in creating something valuable for consumers based on opportunities that are in accordance with desirability, technological feasibility and business strategy viability to 
foster sustainable innovation [15]. The mission of design thinking is to translate observation to inspiration. Inspiration then leads to "the creation of products and services" that will increase the quality of life. This method inspires individuals to have a broad spectrum of innovative activities using human-based design ethos $[15,16]$. In other words, design thinking is acting out the innovation process. This method will help reveal hidden needs and opportunities, as well as create new solutions.

However, in reality, the tendency of "satisficing" must be taken into consideration [17]. The satisficing theory states that human beings are constrained by bounded rationality when making decisions and solving problems. As a result, they are not able to maximize the outcome $[17,18]$. Hence, when developing a product concept, the best option from a set of alternatives cannot be determined, because there are no alternatives. Therefore, there is the need to choose an alternative that best meets the design criteria. This is the essence of design thinking (D-Thinking) in producing something.

Design thinking focuses on innovative solutions. The data collection process is aimed at obtaining inspiration through benchmarks and trend observation. This search includes consumer needs and desires, technological capabilities, communities, and financial availability. It requires awareness of consumers' needs and desires and the ability to build people's expectation of a better life. The discovery of technological and community capabilities encourages the community to make changes. On the other hand, financial availability is a limitation that must be overcome by innovative solutions. Focusing on strength will lead to the creation of innovative solutions that will provide more satisfying answers to the existing challenges.

Design thinking allows the culprit to initiate activities with ignorance. In order to unravel new opportunities, design thinking is systematized under the following steps: defining opportunities, presenting and evaluating alternative solutions, making prototypes, testing the market, revising and developing superior alternatives, and choosing and executing the best alternative. For example, in new product development activity, defining opportunities can be done by adopting a famous phrase from Peter Drucker which says, "Converting need into demand." Without diminishing the importance of more conventional approaches such as focus group discussions and surveys to capture consumer voices, design thinking employs a more holistic and integrated approach involving consumers, designers, and the management [19].

The main mission of design thinking is the ability to translate observation to a whole new insight on new opportunities up to the point that it becomes goods and services that consumers really need. To achieve this, empathy is needed. Empathy involves observing and understanding what other say, do, or think. It is a success determinant for solving others' problems and a source of inspiration to find unarticulated needs. In other words, we need to know and care about others in order to come up with meaningful innovations for them.

It will not come as a surprise to see skeptical views on design thinking in the beginning. Using only observation, it will be difficult to use design thinking to invent groundbreaking products, because the products offered are the results of extrapolation from the habits of the user's community up to date. The articulation of opportunities and point of view is done by combining three elements, namely user, need, and insight. User refers to the identity of the user, while need is defined using verbs inspired by the insights.

After successfully defining the opportunities, extra precaution must be taken in the next phase as it may be ambiguous. Unless carefully followed, the stages of developing a concept may turn out to be misleading. One solution is to generate possibilities to reduce the ambiguity. However, the ideation process must be broad enough for various solutions, while at the same time, narrow enough to generate specific solutions. Once the ideation process is complete, a rapid prototype can be made to improve and test understanding [15]. We must bear in mind that the design is made to think and not the other way around.

When using design thinking, decision makers should not follow the rigid pattern of accepting or rejecting a solution. Rather, they must be open to the possibility of using a combination of several alternatives. Decision making, in essence, is an art. Design thinking 
becomes meaningful because problem solvers have limitations. By nature, we tend to satisfy, rather than maximize. The next section will discuss the methods used to develop innovative footwear designs for this research.

\section{RESEARCH METHODS}

This research is a qualitative research. The research informants consist of six footwear customers, four manufacturers, four government officers, and an academician. Snowball sampling was used to select the fifteen informants. Two separate Focus Group Discussions (FGDs) were used to collect the primary research data. Additionally, observation and documentation were used as secondary data. The data analysis was performed within the Modified Design Thinking framework, and could be formulated as such:

Step 1: The use of customer insight to define opportunities

Step 2: The presentation and evaluation of alternative solutions

Step 3: Prototype creation

Step 4: Market testing
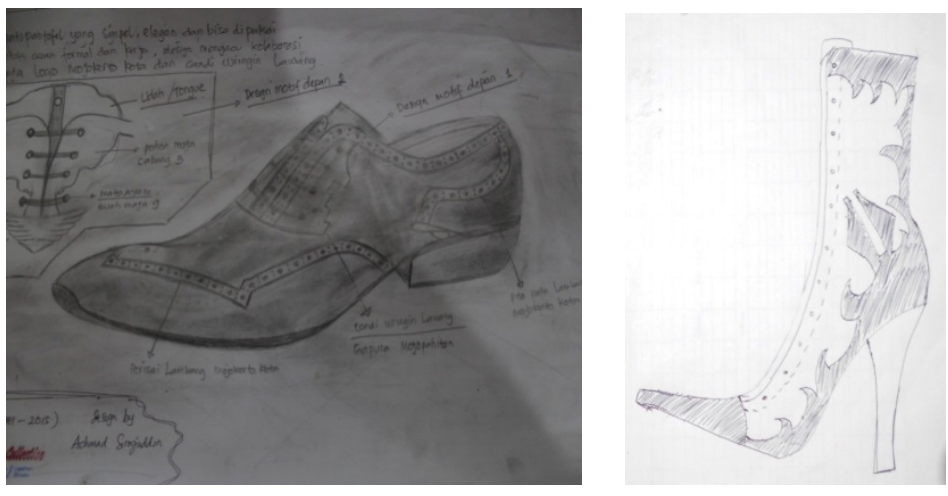

1. Majapahit Oxford Model
2. Heel Boot Model
Step 5: Standardization of footwear quality

\section{DATA ANALYSIS AND DISCUSSION}

The key points of the focus group discussion can be summed up into the following steps:

\section{Step 1: The Use of Customer Insight to Define Opportunities}

The footwear development model for Mojokerto was based on the customer insights into the modern market. To learn more about consumer profiles and design trends, several visits were made to a number of shopping centres around Surabaya, including Surabaya Plaza, Tunjungan Plaza, and Ciputra World Mall. The visit to Surabaya Plaza was conducted to get an overview of the footwear design trends favoured by middle-class consumers. Meanwhile, the Tunjungan Plaza and Ciputra World Mall visits were used to obtain similar data from topmiddle-class consumers. Based on the customer insights and footwear design trends, a blend of modern and traditional styles was used to design the footwear shown in Figure 1 below.

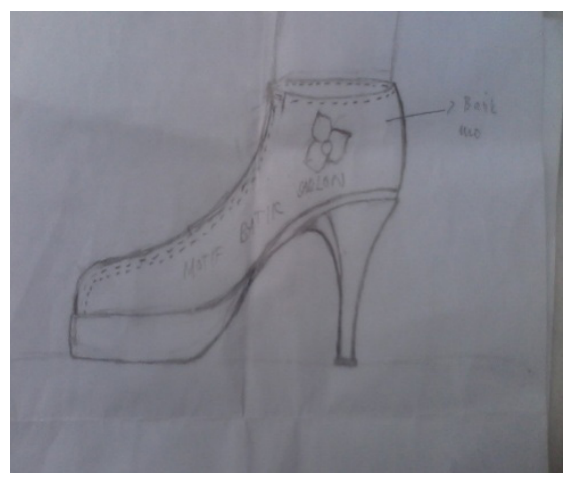

3. High Heel Model

Figure 1. Fashion Footwear Designs Based on Customer Insights

Figure 1 illustrates the designs for the Majapahit Oxford, heel boot, and high heel models. The tongue-shaped design of the Majapahit Oxford model represents the maja tree, maja fruit, and the Archway of Wringin Lawang, which serves as a symbol for the fourteenth-century Majapahit kingdom gate. In addition, the shield symbol of Mojokerto is branded on the top part of the shoes. In general, the Majapahit Oxford model is simple, elegant, and suitable for both formal and casual occasions. 

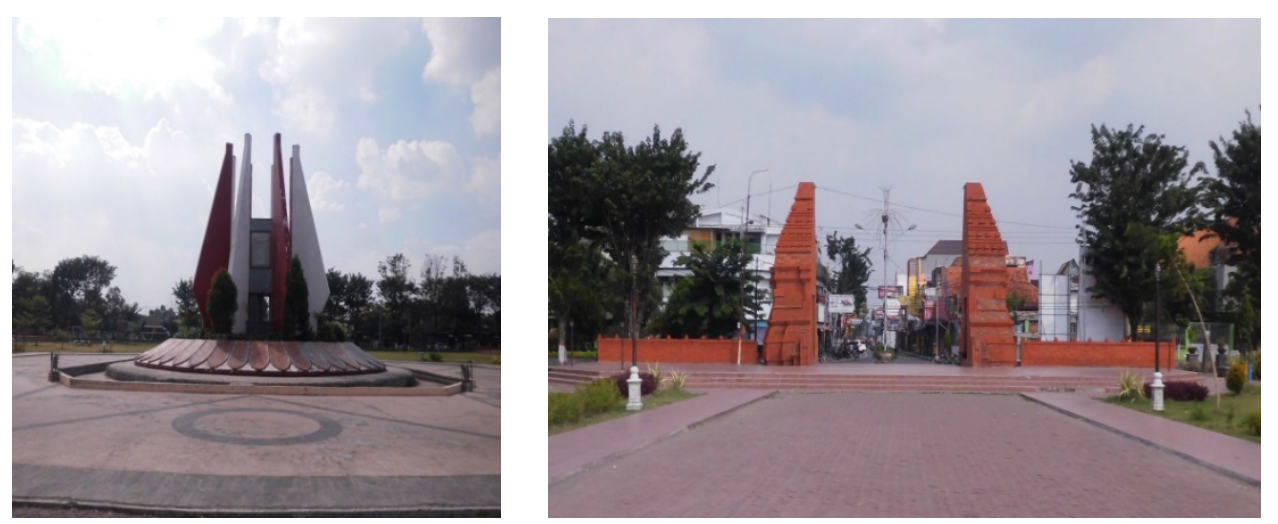

Figure 2. The Archway of Wringin Lawang as a Symbol of the Majapahit Kingdom

The heel boot design also incorporates the Wringin Lawang gate. This model is intended for dinner events and is designed to look antimainstream, attractive, beautiful, and elegant. At the same time, it creates simple, casual, and cool look, particularly for women with smaller body size than the average women. In general, heel boots give the illusion of added height and are perfect for people with long legs. Meanwhile, the high heel model is designed as a closed toe heel with Batik pattern, regardless of the suggestion that most women prefer open toe heels because they are more common and fashionable.

\section{Step 2: The Presentation and Evaluation of Al- ternative Solutions}

The three aforementioned designs were presented and evaluated at the focus group discussion. Some informants approved the designs and recognized the symbols of Mojokerto. The footwear designs, the heel boots in particular, were believed to be in accordance with the youth and young-adult market segments which include people between the ages of fifteen and thirty. The potential of this market reaches up to fifty percent of the national footwear market.

One suggestion from the focus group discussion was to develop the Majapahit Oxford model first before developing the other two models. Participants believed that the other two models had limited usage and appeal, as they were not in line with the current market trends. They also recommended expanding the utility of the heel boots to more than just dinner events. As for the high heels, open toe heels were preferred by the participants because they looked more fashionable.

One participant mentioned that Mojokerto had many artefacts which represented the city's identity, such as Majapahit sun and the maja tree. These ornaments are the symbols of the Majapahit kingdom. Once the design concept was agreed, participants selected the materials for the footwear prototype at PT. Karya Mitra. Leather and accessories were eventually chosen as the materials. However, these materials are very difficult to obtain in retail.

\section{Step 3: Prototype Creation}

The prototype creation began with the computer design, then followed by the top-part process by making the main form. The process is then followed by outsole process, assembling, and finishing. The computer design is shown in Figure 3 below.

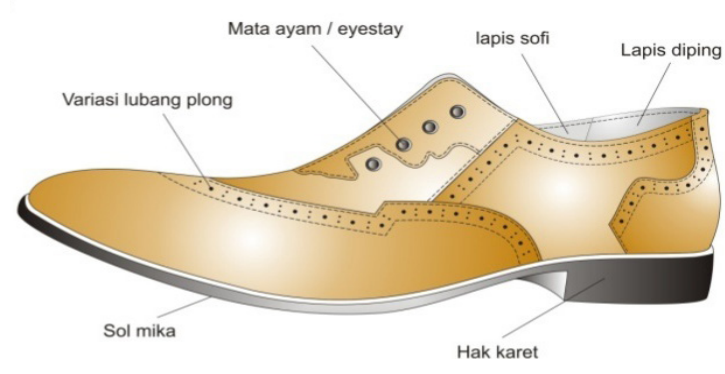

Figure 3. The Computer Design of the Majapahit Oxford Model

Figure 3 describes the material specifications of the top-part, insole, and outsole. The top-part materials consist of fullgrain or brush-off leather and lax with the mixed colour of olive tan. By default, the materials create a shiny surface, and are easy to clean. Even without regular polishing, the surface of 
the skin pores will still look natural. The top part also uses an inner layer called lining. The lining materials are a mixture of combed cotton, sofi imitation, and dipping material imitation.

Meanwhile, the insole material uses two layers called the top and bottom parts. The top part uses Texon coated with combed cotton. Combed cotton is chosen because it uses cool and limp fabrics, and has finer fibre than carded cotton in general. The bottom part, on the other hand, uses TW to maximize strength. Finally, the outsole material is made from a mix of Javarino and rubber soles. Rubber sole is used because it is relatively lighter, less slippery, and more flexible in movement.

The top-part process involves creating a main form for the design pattern, drawing patterns on the leather's surface, cutting and skiving, and folding the leather's edge after it is glued with latex, as shown in Figure 4 below.

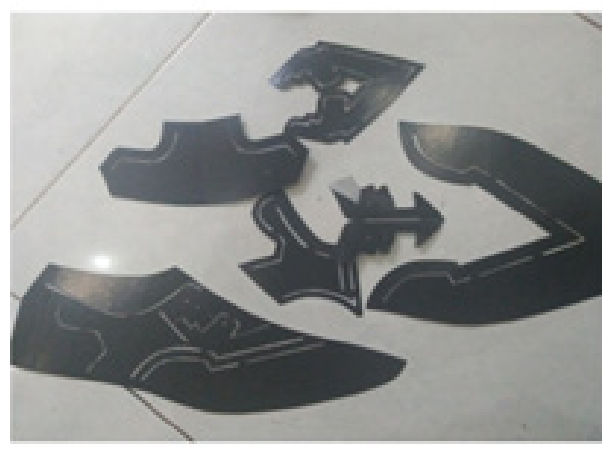

Creating the main form of the design pattern

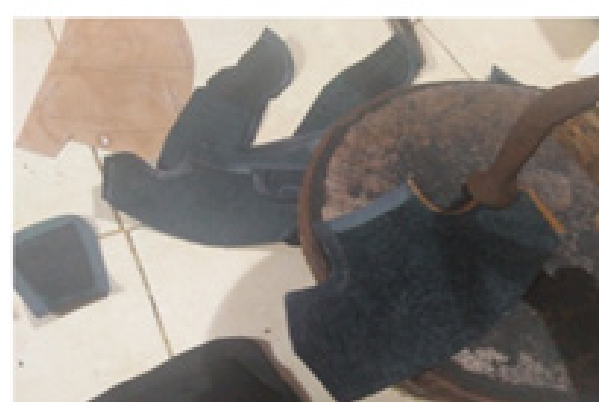

Folding the edge of the leather after it is glued with latex
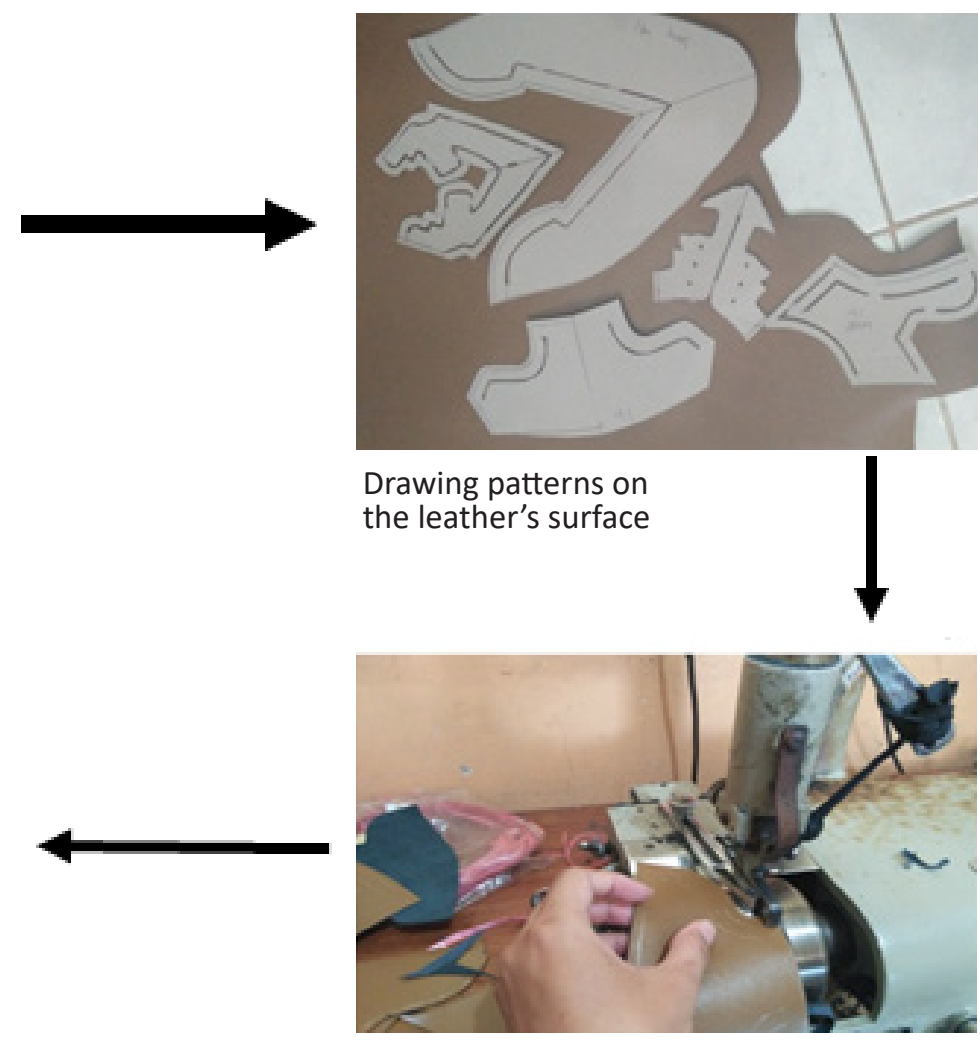

Skiving process

Figure 4. The Top-part Process (Step 1)

The cutting process is the process of cutting raw materials before they are shaped into the top part of the shoes. The leather is cut to form cardboard patterns according to the sample pattern prepared in advance. After the raw material is cut based on the pattern, it is sewn part-by-part onto the top part using the stick cotton technique to make the seams invisible, as shown in Figure 5 below. 


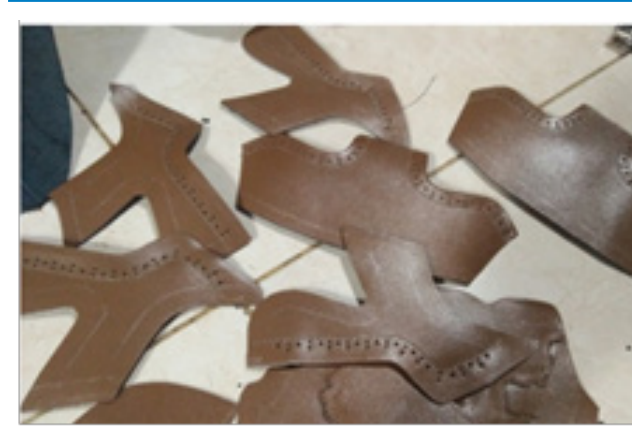

Stitching results of the top part

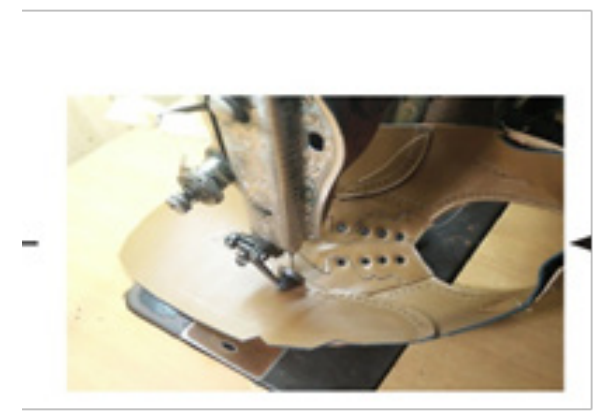

Sewing the parts of the top Part
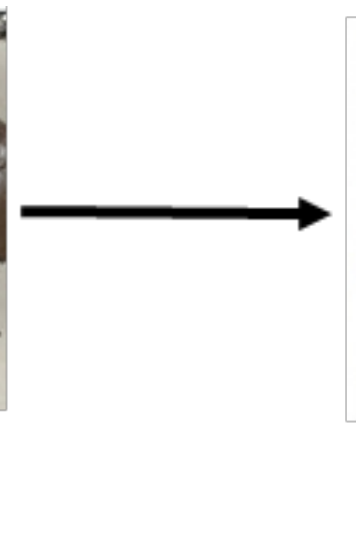

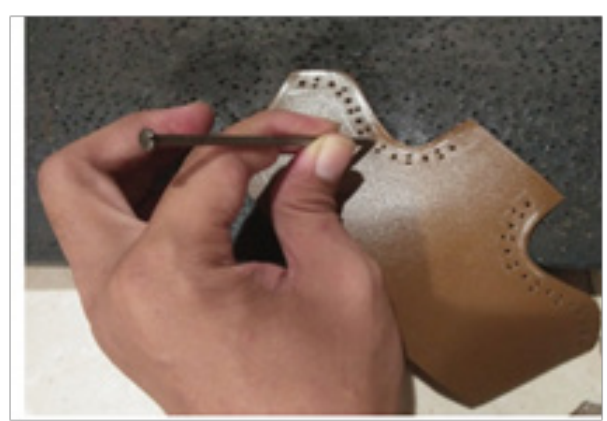

Creating hole variations with the help of a leather punch

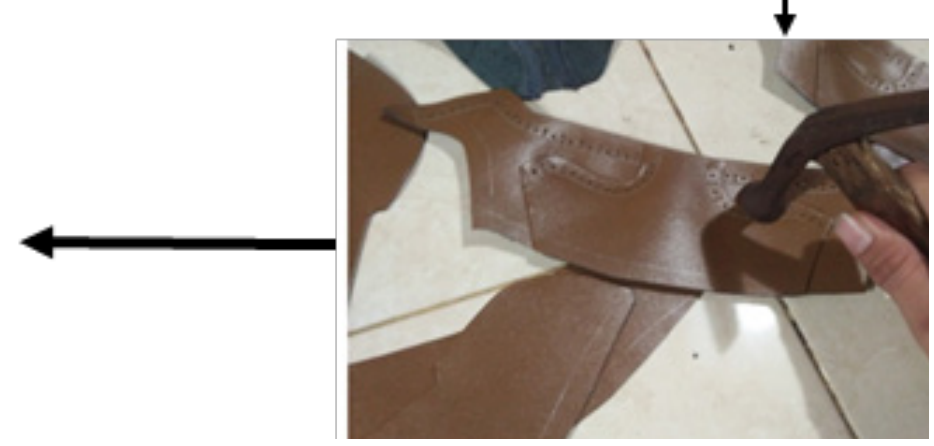

Sticking the parts onto the top part according to the work order

Figure 5. The Top-part Process (Step 2)

After the top-part process is completed, the next step is initiating the bottom part process. This process is divided into two parts: outsole production and insole production. Outsole is the bottom part of a shoe which makes a direct contact with the ground. The characteristics of a good outsole are, among others, durable, waterresistant, and firm grip. Meanwhile, insole is the inner part of a shoe which makes direct contact with the sole of the feet. The insole material will determine the comfort level of the shoe.
Once the top and bottom parts are completed, the next process is attaching the top part to the bottom part. This process is known as assembling, as shown in Figure 6. It starts by cementing the bottom part of the top side using special glue. During the assembling process, the top and bottom parts come in pairs with predetermined size. In order for the shoe form to match the foot contour, Laste is used. And finally, compressor press is performed to provide maximum pressure. 


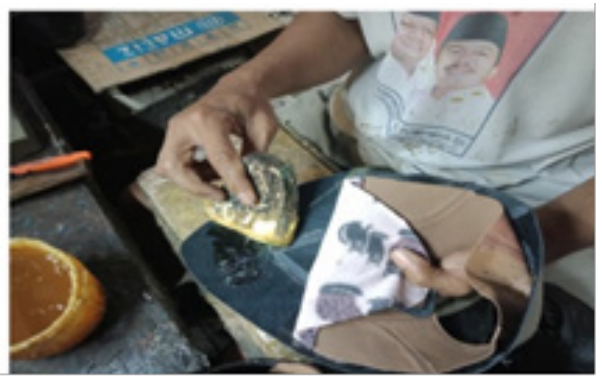

Cementing the bottom part of the top side
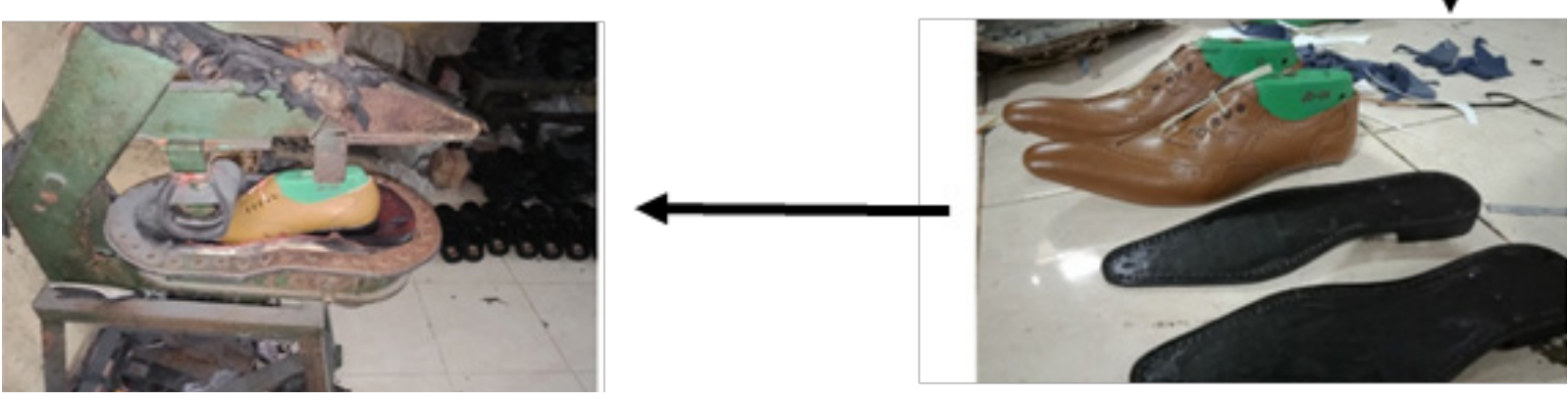

Compressor press

Figure 6. Assembling Process

The next stage of the prototype creation is the finishing process, as shown in Figure 7 below.

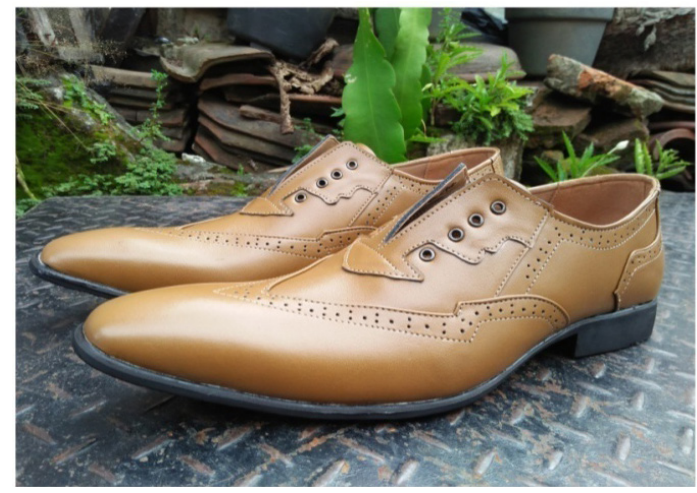

Figure 7. Finishing Process

This stage involves cleaning the glue and ink residue with gasoline or liquid F4, painting the sides of the sole with black car paint, putting lining under the insole, spraying paint with clear gloss paint, and attaching a shoelace and other accessories.

\section{Step 4: Market Testing}

The completion of the prototype is followed by market and shoe-quality tests. The purpose of the market test is to determine the market's response to the design and quality of the footwear prototype. Meanwhile, the durability test was conducted by the Indonesian Footwear Industry Development Center (BPIPI). The durability of the footwear was marked as 2.8 out of 3 , which was the passing standard. This result indicates the use of low-quality or insufficient amount of adhesive. 


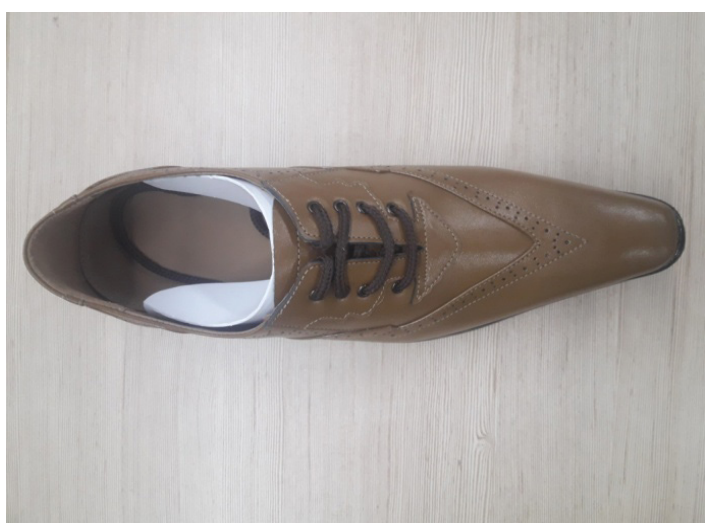

Figure 8. First Prototype

The market tests were conducted twice at the Fashion and Leather Shoe Exhibition (SKF) in Jakarta and Crafina Exhibition in Surabaya. The percentage of positive comments ('good' or 'very good') during the first market test at SKF was shown at $47.73 \%$. This means that the design might not fit the current market trends and preferences.

Based on the feedback, improvements were made on the first prototype shown in Figure 8. Brighter colour and thinner shoelaces were used, while the toe cap was made pointier. Overall, the shoe looked more symmetrical and pleasant-looking, as shown in Figure 9. When the second market test was conducted at the Crafina Exhibition, the percentage of favourable opinion increased to $75.88 \%$. The number confirmed that the improved prototype was more in line with the current market trends and preferences.

\section{Step 5: Standardization of Footwear Quality}

Standardization is needed to certify the production quality of the footwear. The three aspects of standardization are technical, nontechnical, and consumer perception aspects. The complete standardization guideline is as follows:

1. The technical aspects include durability, raw materials, comfort, and progressive designs

2. The non-technical aspects include convenience, adjustment to trend, footwear designs, and stitching quality

3. The consumer perception standards on footwear quality

a. Convenience: $60 \%$ of respondents mentioned 'Comfortable' and

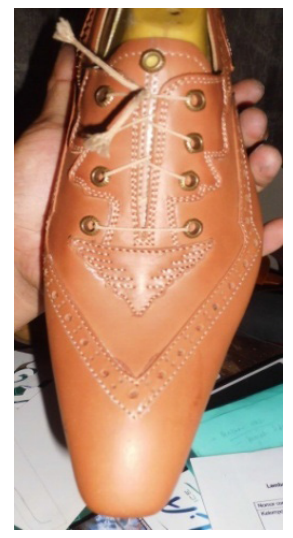

Figure 9. Improved Prototype

opinion assessment team.

b. Adjustment to trend: $60 \%$ of respondents mentioned 'Trendy' and opinion assessment team.

c. Footwear design: $60 \%$ of respondents mentioned 'Good design' and opinion assessment team.

d. Product uniqueness: $60 \%$ of respondents mentioned 'Unique product' and opinion assessment team.

e. Raw materials quality: $60 \%$ of respondents mentioned 'Good raw material quality' and opinion assessment team.

f. Stitching quality: $60 \%$ of respondents mentioned 'Good stitching quality' and opinion assessment team.

\section{IMPLICATIONS}

Modified Design Thinking can be used to find innovative design inspiration based on current market trends and preferences. Since the products generated by the innovation process incorporate local culture in their design, they tend to fit the market's preferences. Additionally, prototypes can be repaired to prevent greater loss in mass production with the help of market testing as a part of the continuous innovation process.

\section{CONCLUSION}

The two main problems encountered by many small and medium-sized enterprises 
in Mojokerto are monotonous design and dependence on imported raw materials. Furthermore, the production process was carried out in a traditional fashion, while the market development was very limited. By implementing Modified Design Thinking, this study concludes that the innovation process in Indonesia is unique as it incorporates local culture into the process. The first market testing at SKF indicated that $47.73 \%$ of the public's opinion leaned towards 'Good' and 'Very good'. Additionally, the percentage of the favourable comments was shown at $75.88 \%$ after the second market testing was conducted.

\section{REFERENCES}

1. Pusat Komunikasi Publik Kementerian Perindustrian, Rencana Induk Pembangunan Industri Nasional 2015 - 2035, 2015, retrieved August 23, 2018, from http://www. kemenperin.go.id/ripin.pdf.

2. Dishubkominfo. Sepatu Mojokerto Siap Memasuki Pasar MEA: Focus Group Discussion (FGD) Penyusunan Standarisasi Produk Alas Kaki UKM, 2016, retrieved August 23, 2018, from http://new.mojokertokota.go.id/home/ readmore_berita/nw2016031513231327.

3. Reguia, C., Product innovation and the competitive advantage, Eur Sci J, 2014, 10, 10.

4. Dereli, D.D., Innovation Management in Global Competition and Competitive Advantage, Procedia Soc Behav Sci, 2015, 195, 1365-1370, https://doi.org/10.1016/j. sbspro.2015.06.323.

5. Angelmar, R., Product Innovation: A Tool for Competitive Advantage, Eur J Oper Res, 1990, 47, 2, 182-189, https://doi. org/10.1016/0377-2217(90)90277-I.

6. Beauregard, Y., Polotski, V., Bhuiyan, N., Thomson, V., Optimal Utilisation Level for Lean Product Development in a Multitasking Context, Int J Prod Res, 2016, 55, 3, 795-818, https://doi.org/10.1080/00207543.2016.121 3448.
7. Bilgili, B., Erciş, A., Ünal, S., Kano Model Application in New Product Development and Customer Satisfaction (Adaptation of Traditional Art of Tile Making to Jewelries), Procedia Soc Behav Sci, 2011, 24, 829-846, https://doi.org/10.1016/j. sbspro.2011.09.058.

8. Balachandra, R., Friar, J.H., Factors for Success in R\&D Projects and New Product Innovation: A Contextual Framework, IEEE Xplore, 1997, https://doi.org/10.1109/17.618169.

9. Hu, Y., Aziz, E.S.S., Chassapis, C., CreativityBased Design Innovation Environment in Support of Robust Product Development, Int J Interact Des Manuf, 2016, 10, 4, 335-353, https://doi.org/10.1007/s12008-014-0242-3.

10. Su, C.T., Chen, Y.H., Sha, D.Y., Linking innovative product development with customer knowledge: A data-mining approach, Technovation, 2006, 26, 7, 784-795, https:// doi.org/10.1016/j.technovation.2005.05.005.

11. Danneels, E., The Dynamics of Product Innovation and Firm Competences, Strateg Manag J, 2002, 23, 12, 1095-1121, https:// doi.org/10.1002/smj.275.

12. Woschke, T., Haase, H., Enhancing New Product Development Capabilities of Smalland Medium-Sized Enterprises through Managerial Innovations, J High Technol Manag Res, 2016, 27, 1, 53-64, https://doi. org/10.1016/j.hitech.2016.04.005.

13. Pink, D., A Whole New Mind, 2005, USA: Penguin Group.

14. Avital, M., Boland, R.J., Design with a Positive Lens: An Affirmative Approach to Designing Information and Organizations, ICIS 2008 Proceedings, https://doi.org/10.1016/S14759152(07)00201-3.

15. Brown, T., Design Thinking, Harvard Business Review, 2008, 86, 6, 84-92.

16. Brown, T., Change by Design: How Design Thinking Transforms Organizations and Inspires Innovation, 2009, New York, NY.: HarperCollins Publishers. 
17. Simon, H.A., Models of Man: Social and Rational, 1957, England: Wiley.

18. Simon, H.A., A Behavioral Model of Rational Choice, The Quarterly Journal of Economics, 1955, 69, 1, $99-118$, https://doi. org/10.2307/1884852.

19. Lockwood, T., The Expanding Influence of Design Management, Design Management Journal, 2010, 5, 1, 3, https://doi.org/10.1111/ j.1948-7177.2010.00017.x.
(C) 2020 by the author(s). Published by INCDTPICPI, Bucharest, RO. This is an open access article distributed under the terms and conditions of the Creative Commons Attribution license (http:// creativecommons.org/licenses/by/4.0/). 